\title{
Current situation and population trend of the lesser spotted eagle (Aquila pomarina) in Hungary
}

\author{
Súčasný stav a populačný trend orla krikl’avého (Aquila pomarina) v Mad'arsku
}

\author{
Ádám PONGRÁCZ \& Tamás SZITTA
}

\begin{abstract}
First reports on the population of the lesser spotted eagle in Hungary appeared between 1978 and 1982 , and based on these data, we estimate that their population was about 90 pairs during that period. By 2014 this number had decreased to below 40 pairs. The species disappeared from its former nesting sites in the lowlands, riparian habitats and also in a few hilly and mountainous areas. The reasons for its decline appear complex in Hungary. Changes in agricultural practice are suspected of being one of the main reasons which are discussed in the article. We presume that populations of prey species were also negatively affected. Decrease in undisturbed forest stands older than 100 years was probably also a significant factor affecting nesting habitats. As a marginal population, it greatly depends on the larger ones in the surrounding countries, and it is also affected by mortality during migration. Positive changes in the past four years in agricultural land use have already caused a slight increase in their numbers. Main tasks for the near future should be the establishment of a special support scheme focusing on the species' foraging habitats.
\end{abstract}

\begin{abstract}
Abstrakt: Prvé správy o vel'kosti populácie orla krikl’avého v Mad’arsku sa objavili v rokoch 1978 až 1982 . Na základe týchto údajov odhadujeme, že ich populácia bola vtedy tvorená asi 90 pármi. Do roku 2014 sa tento počet znížil pod 40 párov. Druh zmizol z jeho predošlých hniezdísk v nížinách, z lužných lesov a tiež z niekol'kých pahorkatinných a horských oblastí. Príčiny úbytku jeho populácie v Mad'arsku sa zdajú byt' komplexné. Zmeny v pol'nohospodárstve pokladáme za jeden z hlavných dôvodov tohto úbytku, čo aj diskutujeme v tomto príspevku. Predpokladáme, že populácie jeho koristi boli tiež negatívne ovplyvnené. Úbytok nenarušených lesných porastov starších než 100 rokov je pravdepodobne tiež významným faktorom v hniezdnych habitatoch. Ked’že mad'arská populácia orla krikl'avého je populáciou na okraji areálu rozšírenia, je vel'mi závislá na väčších populáciách v okolitých krajinách; tiež je ovplyvnená mortalitou počas migrácie. Pozitívne zmeny vo využívaní pol’nohospodárskej pôdy v posledných štyroch rokoch už spôsobili mierny nárast početnosti populácie. V blízkej budúcnosti by malo byt’ hlavnou úlohou zavedenie osobitného režimu dotácií, zacieleného na kvalitu potravných habitatov druhu.
\end{abstract}

Key words: lesser spotted eagle, Aquila pomarina, population trend, Hungary

Ádám Pongrácz, Bükki National Park Directorate, Sánc u. 6, H-3304 Eger. E-mail: pongracza@bnpi.hu.
Tamás Szitta, Bird Life Hungary, Költő u. 21, H-1121 Budapest. E-mail: tamas.szitta@gmail.com.

Acknowledgements: Special thanks to Gábor Papp for the translation of this article.

\section{Introduction}

The Hungarian population of Aquila pomarina is only a fraction of a much larger one distributed throughout the countries of the Carpathian Mountains (Romania, Poland, Ukraine, and Slovakia). Nowadays, the Hungarian pairs nest exclusively in foothills and hill country. Today, the distribution of the species is restricted to the north Hungarian highlands (Zemplén Hills, AggtelekiKarst, Bükk Hills, Mátra Hills) and Southern Transdanubia (Kelet-Mecsek Hills, Tolnai and Szekszárdidombvidék) (Pongrácz et al. in prep.). In the previous decades, there were a few pairs nesting in the KeletCserhát, the Bereg-Szatmári Plain, the Börzsöny Hills, the Inner Somogy, the Gödöllö Hills and the Pilis
Mountains. Nevertheless, these pairs have now disappeared. Until the 1950s, lesser spotted eagles also nested in the riparian forests of the lowlands (e.g. along the Tisza River, Hármas- (Triple-) Körös River, Gemenc, Hanság) (Studinka 1956, Horváth 1976). In these areas recently there have been no observations of breeding pairs, with the exception of one breeding attempt and two additional territorial pairs three or four years ago. Nesting in such habitats has only been confirmed on the other side of the country border. In 2009, lesser spotted eagles occupied newly established territories in the Szatmár region and the Nagy-Sárrét area in 2009, and later in 2010-2011 in the floodplains of the Maros River, close to the border, but on the Romanian side 
(Pongrácz et al. 2012, 2014).

The aim of this report is to present the changes in the population of Aquila pomarina in Hungary, and to correct the population estimates made in 1980-1990. Furthermore, we make an attempt to answer the question of what might have caused the serious decline in the local population.

\section{Material and methods}

Since we intended to process all the data about the national population in order to find the reasons for its decline, first we collected articles and literature reports on observations and distribution of the lesser spotted eagle in Hungary. Based on these data, we made an attempt to compile its distribution in different periods and to draw conclusions about the population trends. We tried to clarify the controversial population estimates using nationwide data from the period of 2008-2014 and regional data from the decades prior to that. We used our observations and experience compiled in the past few decades. Additionally, we collected data about environmental factors, changes in which might have influenced and caused the population decline since the beginning of the study of the species.

\section{Results and discussion}

Considering the population estimates found in the literature, e.g. 45-50 pairs (Haraszthy 1984), 90 pairs (Haraszthy \& Bagyura 1993), 150 pairs (Haraszthy et al. 1996), 100 pairs (Báldi et al. 1997), the authors conclude that the population size of 150 pairs could only have occurred prior to the 1960s. There are even data available about regular lowland nesting in the literature from the 1960's (Studinka 1956, Horváth 1976), which does not take place at present. Comparing older data with the current estimate of about 40 pairs, which is based on nationwide surveys, it is not possible to establish any reason for such drastic population decrease which could explain the reduction of the Hungarian population by two-thirds. The largest decline occurred in the Zemplén Hills, where 25 pairs were known in the early 1990's (Szegedi, pers. comm.), which had dropped to 13 pairs by 2014 (Pongrácz et al., in prep.). The Bükk Hills and their surroundings held twelve pairs in the 1990's (Szitta, unpublished data), and this has not changed since then (Pongrácz et al. 2014). There were two pairs of lesser spotted eagles in the Mátra Hills in 1996 (Szitta, unpublished data), as well as in 2014 (Pongrácz et al., in prep.). However, the disappearance of nesting pairs from certain traditional territories in the hill country and mountainous areas (e.g. Börzsöny Hills, Cserhát Hills, Pilis Hills, Inner Somogy and Gödöllő Hills) as well as in lowland habitats (e.g. Szatmár) most likely contributed to a modest population decrease. In the 1990s there were no nationwide surveys, and the population estimates were calculated based on data obtained from a few regions. Subsequent field trips proved that the species nested in much lower numbers or did not nest at all in those areas where population figures were only extrapolated. Since 2004 there have been surveys covering the whole distribution of the lesser spotted eagle in Hungary, resulting in more precise data. Nevertheless, current data suggest a population decrease of more than $50 \%$, when the estimated population of 90 pairs in the 1990s fell below the 40 pairs of today (Pongrácz et al. in prep.). Data from the period between 1978 and 1982 came from the early years of practical species conservation. Since only part of the nests and territories were known at that time we consider this estimate as an approximation. At that time fewer people studied the lesser spotted eagle and other raptor species compared to the current situation. Thus in Hungary a serious population decline has been observed despite the legal protection of the species since 1954 .

However, exact calculation of this population trend is prevented due to several factors. First of all, published estimated population trend numbers vary considerably from year to year (e.g. 1982, 1992, 1996, and 1997; Table 1).

These data suggest that the population estimated to be around 100 pairs in the 1990 s had shrunk to around 30-40 pairs in 2004-2014. Some publications stated that the breeding population consisted of 150 pairs in the 1990s (Tab. 1). Due to this estimate, the European species conservation plan, written up for the lesser spotted eagle in 1997 (Meyburg et al. 2001), includes this figure (Haraszthy et al. 1996). The authors of this publication and several other species experts believe that this number was somewhat overestimated in the 1990s, since with the exception of a few territories, the species had already disappeared from the lowlands by that time.

In Hungary, practical conservation of the lesser spotted eagle started in 1977. First, nesting pairs needed to be mapped. Following this, the main goal was to protect the known nesting sites. Another important part of the conservation was the effort to rescue second chicks because of the well-known phenomenon of the species called cainism. Altogether, 14 chicks were rescued suc- 


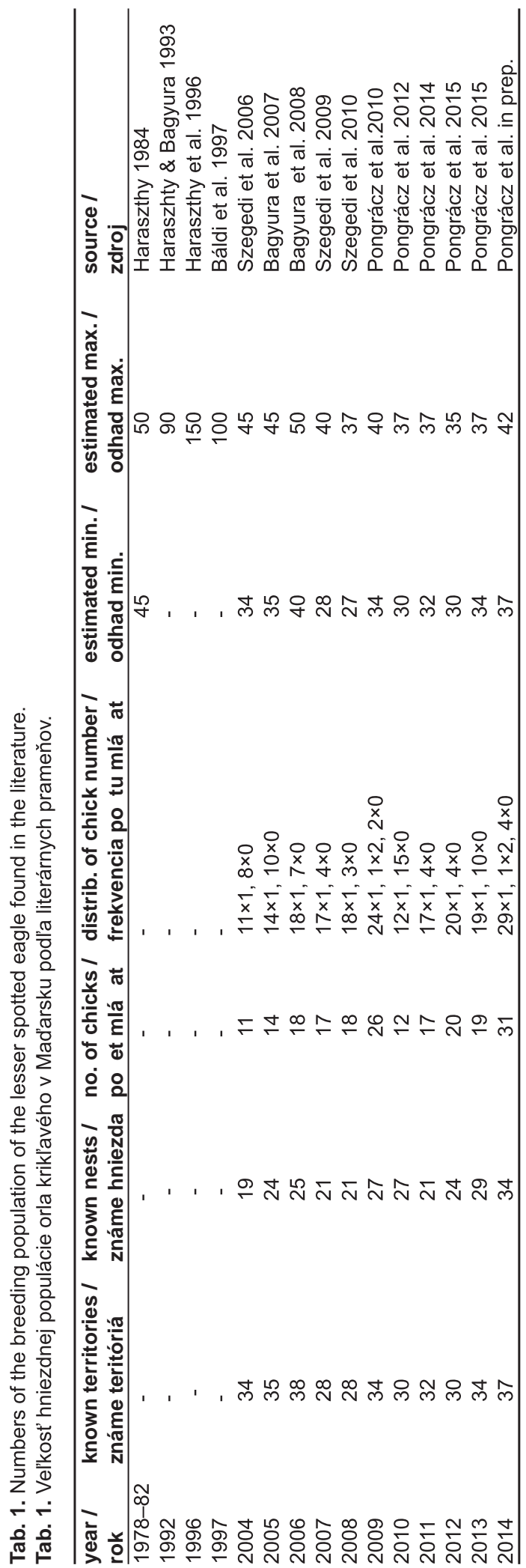

cessfully by 1993 (Haraszthy \& Bagyura 1993). Nowadays, this technique is not employed any more since its positive effect on the population was found to be negligible.

Currently, the species protection consists of monitoring nesting sites and applying temporal and spatial restrictions around the nests. Temporal restrictions apply in a $400 \mathrm{~m}$ radius circle around each nest to prevent human activities from disturbing the birds. These activities include forestry work, hunting and occasionally tourism.

Spatial restriction is used to save the nesting habitat, and applies to a $300 \mathrm{~m}$ radius circle around each nest all year round. Its primary aim is to protect the older forest stands. In connection with this, logging is prohibited within a radius of $100 \mathrm{~m}$ from each nest, and only selective felling can be done outside of this area. Restrictions are authorized by the relevant nature conservation authorities. In the case of protected and NATURA 2000 areas, restrictions also become registered in forest management plans. In Hungary, artificial nests are built only for replacement of destroyed nests (Fig. 1). In most cases a pair started to occupy in these nests in subsequent years.

A major problem is that practical species protection does not address foraging areas, so it does not try to mitigate adverse changes to these habitats.

The main assumed reasons for the decrease in the Hungarian population of Aquila pomarina: A major decrease in the local breeding population occurred after the change in the political situation in the 1980s and 90s. It arose from two sources: negative changes in both nesting and foraging habitats.

Changes in the foraging habitats: Drastic transfor-

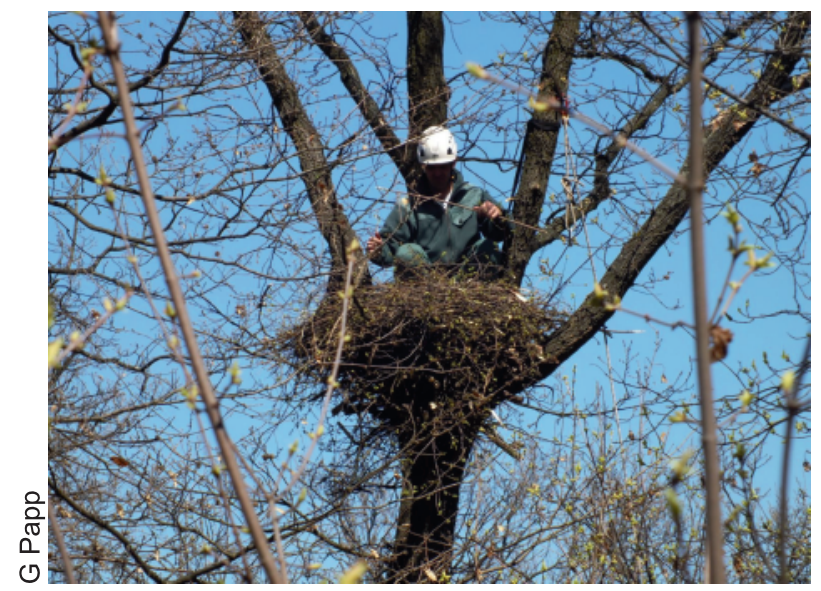

Fig. 1. Building artificial nests for the lesser spotted eagle.

Obr. 1. Stavba hniezdna pre orla krikl'avého. 
mations took place in agricultural practice in the abovementioned period. Large-scale farming stopped operating in several places. The extent of cultivated land shrank primarily in less fertile lands. Cooperative farming systems ceased to exist first in such areas. Characteristically, these less fertile lands included foothills and hill country areas, which are prime foraging habitats for the lesser spotted eagle.

This decline was continuous in the past decades (1970-2013) and quantified as follows. Grasslands decreased by $41 \%$, from $1,280,000$ hectares to 760,000 hectares. Grazing on forest pastures in the foothills stopped, resulting in spontaneous forest regrowth. The amount of arable land dropped by $15 \%$, from 5,040,000 hectares to 4,325,000 hectares. The acreage of cultivated crops changed significantly as well. The acreage of lucerne decreased by $66 \%$ from 395,000 hectares to 134,000 hectares. Certain crops increased, however they proved to be unsuitable for the species as a foraging source. Sunflower cultivation grew by $625 \%$, from 91,200 hectares to 597,000 hectares, and rape planting increased by $707 \%$, from 28,000 hectares to 198,000 hectares. All in all, the acreage of cereals decreased by $18 \%$, from $1,750,000$ hectares to $1,450,000$ hectares. At the same time, similar changes occurred in livestock farming. Numbers of cows, horses and sheep, which determine grazing the most, fell by $53 \%$, from $4,449,000$ individuals to $2,058,000$ individuals. Of these, the number of cows dropped from 1,911,000 to 782,000 , sheep from $2,316,000$ to $1,214,000$ and horses from 222,000 to 62,000 . Moreover, grazing was pushed

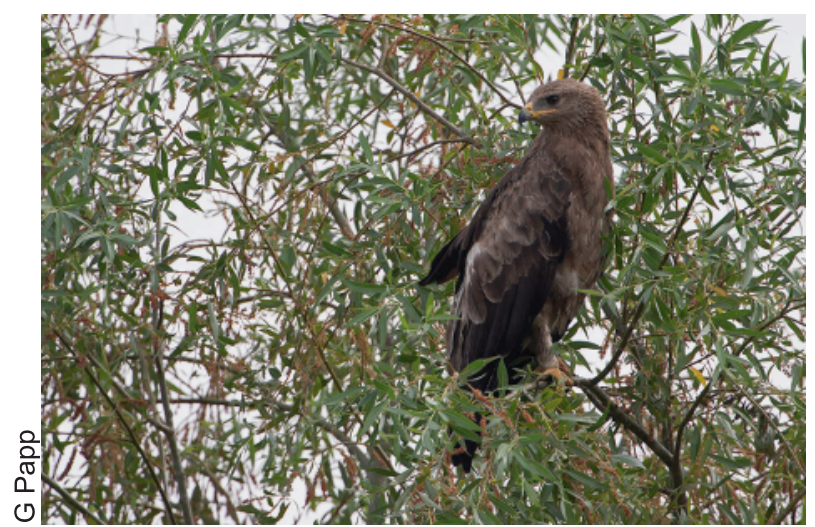

Fig. 2. Lesser spotted eagle with Slovakian ornithological ring from the Zemplén Hills, 25 June, 2014.

Obr. 2. Orol kriklavý so slovenským ornitologickým krúžkom pozorovaný v pohorí Zemplén, 25. jún 2014. into the background, and intensive animal farming became dominant, which induced further decrease in the extent of grazed lands (Hungarian Central Statistical Office 2015).

These changes led to less availability of two important prey species, namely the common vole (Microtus arvalis) and the European hamster (Cricetus cricetus) (Haraszthy et al. 1996), near the lesser spotted eagles' typical breeding habitats. The latter species underwent a catastrophic decline in Hungary.

Negative changes in nesting habitats: Nesting habitats also suffered negatively. During the interwar period (between World War I and II), large-scale clear cutting, sometimes reaching up to 1000 hectares, was carried out in several large forested areas. These forests have reached their maturity nowadays, and forestry work has started in them. Therefore the extent of older, managed forest stands, which are suitable for nesting and close to foraging areas, has further shrunk.

On several occasions, the imperial eagle appeared in the neighbourhood as a nesting species and pushed lesser spotted eagles out of their traditional territories. In such cases, the smaller, weaker species has always abandoned the area, and these two species have never bred together. The authors are aware of four cases of such interactions in the Bükk Hills.

We do not know about the rate of mortality during migration, or whether immature birds return to breed in Hungary, and if not, then where new mates come from to replace missing birds. It is highly likely that these originate in Slovakia and Poland (Fig. 2). We suspect that several birds from the local population perish every year during migration.

Another important factor affecting our population stems from changes in the surrounding countries. Fluctuations occurring in these areas (Slovakia, Romania and Ukraine) may greatly influence the Hungarian breeding population.

In 2014, the national population of lesser spotted eagles was around 37-42 pairs. The entire population has been monitored in Hungary. Based on our observations, we suspect that specific information is lacking only for 1-5 pairs annually. Thorough monitoring was carried out in the past ten years. A serious decline, exceeding $50 \%$, devastated the population in the past 25 years. We estimate numbers of eagles at 70-90 pairs during the 1980-90s. The main probable reasons for the decline are unfavourable changes in agricultural practices creating disadvantageous conditions in foraging 
habitats, and furthermore, disappearance of older forests in nesting areas.

In the past five years we have experienced a slight increase in the number of breeding pairs. The reason for this may be the systematic protection of the nesting habitats and locally, the cultivation of once-abandoned foothills due to agricultural aid schemes. As described above, it is not enough to apply restrictions around the nests; we also have to focus on the foraging habitats if we want to effectively protect the species. It would be worthwhile to develop a support scheme which could provide optimal conditions in the hunting grounds of the species.

\section{References}

Bagyura J, Szitta T, Szegedi Z \& Kováts L 2007: Békászó sas állomány adatok - 2005 [Population of lesser spotted eagle - 2005]. Heliaca 3: 46-48. [In Hungarian]

Bagyura J, Szegedi Zs, Szitta T, Harmos K \& Kováts L 2008: Békászó sas állomány adatok - 2006 [Data on breeding populations of lesser spotted eagle 2006 ]. Heliaca 4: 46-47. [In Hungarian]

Báldi A, Moskát Cs \& Szép T 1997: Nemzeti Biodiverzitás Monitorozó Rendszer IX. Madarak - 1997. [National Biodiversity Monitoring System IX. Birds] 80. [ In Hungarian]

Haraszthy L 1984: Magyarország fészkelő madarai [Nesting birds of Hungary]. Natura, Budapest 56-57. [In Hungarian]

Haraszthy L \& Bagyura J 1993: Ragadozómadárvédelem az elmúlt 100 évben Magyarországon [Protection of raptors in the last 100 years in Hungary]. Aquila 100: 105-121. [In Hungarian]

Haraszthy L, Bagyura J, Szitta T 1996: Zur Biologie des Schreiadlers Aquila pomarina in Ungarn, 305-312. In: Meyburg B-U \& Chancellor RD (eds), Eagle Studies. World Working Group on Birds of Prey Berlin, London \& Paris, 549.

Horváth L 1976: A békászó sas (Aquila pomarina) szokatlan előfordulása [Unusual data of lesser spotted eagle (Aquila pomarina)]. Aquila 83: 282. [In Hungarian]

Hungarian Central Statistic Office 2015: Agricultural database. Retrieved April 1, 2015, from: http://www.ksh.hu/agrarcenzusok_hosszu_idosorok_t- ablak. [In Hungarian]

Meyburg B-U, Haraszthy L, Strazds M \& Schäffer N 2001: European species action plan for the lesser spotted eagle. In: Schäffer N \& Gallo-Orsi U (eds), European Union action plans for eight priority bird species. European Commission, Luxembourg, 247.

Pongrácz Á, Szegedi Zs, Kováts L, Szitta T, Bank L \& Tóth I 2010: Békászó sas állomány adatok - 2009 [Population of lesser spotted eagle - 2009]. Heliaca 7: 72-73 [In Hungarian with English summary]

Pongrácz Á, Szegedi Zs, Kováts L, Szinai P \& Bank L 2012: Békászó sas állományadatok - 2010 [Population of lesser spotted eagle - 2010]. Heliaca 8: 46-47. [In Hungarian]

Pongrácz Á, Szegedi Zs, Kováts L, Szinai P \& Bank L 2014: Lesser spotted eagle population report - 2011 [Lesser spotted eagle population report - 2011]. Heliaca 9: 34-35. [In Hungarian with English summary]

Pongrácz Á, Szegedi Zs, Kováts L, Szinai P, Bank L \& Farkas R 2015: Békászó sas (Aquila pomarina) állomány adatok - 2012 [Population of lesser spotted eagle (Aquila pomarina) - 2012]. Heliaca 10: 34-35. [In Hungarian with English summary]

Pongrácz Á, Szegedi Zs, Kováts L, Szinai P, Bank L \& Farkas R 2015: Békászó sas (Aquila pomarina) állomány adatok - 2013 [Population data of lesser spotted eagle (Aquila pomarina) - 2013]. Heliaca 11: 34-35. [In Hungarian with English summary]

Studinka L 1956: Faunisztikai megfigyelések a Hanságból [Zoological data from Hanság]. Aquila 63-64: 312-313. [In Hungarian]

Szegedi Zs, Szitta T, Pongrácz Á, Kováts L, Siklósi M \& Bank L 2006: Békászó sas állomány adatok 2004 [Population of lesser spotted eagle - 2004]. Heliaca 2: 31-32. [In Hungarian]

Szegedi Zs, Szitta T \& Kováts L 2009: Békászó sas (Aquila pomarina) állomány adatok - 2007 [Data on breeding populations of lesser spotted eagle - 2007]. Heliaca 5: 63-64. [In Hungarian with English summary]

Szegedi Zs, Szitta T, Kováts L \& Bank L 2010: Békászó sas (Aquila pomarina) állomány adatok - 2008 [Data on breeding populations of lesser spotted eagle - 2008]. Heliaca 6: 42-43. [In Hungarian with English summary] 